\title{
Hematinic Deficiency and the risk of Oral Epithelial Dysplasia
}

\author{
Mohamed A Jaber* \\ Hamdan Bin Mohamed College of Dental Medicine, Mohammed Bin Rashid University of Medicine and Health Sciences, UAE
}

\begin{abstract}
Oral squamous cell carcinoma could be preceded by clinically evident oral potentially malignant disorders harboring oral epithelial dysplasia (OED. Hematinic deficiencies are associated with certain potentially malignant disorders and cancerous lesions. The aims of this study were: to evaluate the circulating levels of vitamin $\mathrm{B}_{12}$, folate status in patients with OED and to assess the impact tobacco smoking on these levels. To evaluate the circulating level of vitamin $\mathrm{B}_{12}$, serum folate, red blood cells folate among OED patients. Data were collected from 120 patients with OED and 120 healthy control Subjects matched for age and gender, selected from patients with oral diseases not caused by tobacco or alcohol or related to knowing hematinic deficiency. Most of patients with OED were current smokers of more than 20 cigarettes per day for more than 20 years compared with normal healthy control. A significant decrease in the serum levels of folate, red blood cell folate was found in OED compared to normal tobacco smokers $(p<0.05)$. No significant differences in vitamin $\mathrm{B}_{12}$ was found between OED cases and normal control subjects. These findings support the notion that OED may develop in persons who expose to tobacco smoking and have low folate level.
\end{abstract}

\section{Introduction}

Epithelial dysplasia represents the sum of various disturbances of epithelial proliferation and differentiation as seen microscopically. Individual cellular features of dysplasia are called epithelial atypia. Dysplastic epithelium characterized by alteration in the part of the thickness of the epithelium, which replaced by cells showing varying degrees of cellular atypia and maturational disturbances [1]. OED may occur in clinically identifiable lesions including erythroplakia, leukoplakia and erythroleukoplakia [2], These clinically defined lesions have been stated to harbor an increased risk compared to normal mucosa for transformation into squamous cell carcinoma. [3,4] Studies reported transformation rates ranging from 6.6 to $36.4 \%$ after mean follow-up periods of 1.5 to 8.5 years $[1,5,6]$.

Tobacco and alcohol use is accepted as the most important risk factors for oral potentially malignant lesions $[7,8]$ and OED [912]. Exposure to cigarette smoke may result in folate deficiency via chemical inactivation and thus render the epithelium more susceptible to neoplastic transformation by the carcinogenic hydrocarbons of tobacco smoke [13].

Some aspects of diet are considered to be associated with the risk of cancer, precancer and OED [14-16] and intake of certain food products such as beta-carotene, vitamin $\mathrm{E}$ and vitamin $\mathrm{A}$, or its analogues may cause regression of oral leukoplakia, thus preventing its progression to malignancy. $[17,18]$ There is evidence that folate deficiency may be involved in the aetiology of carcinoma of esophagus [19], bronchi [20], cervix [21], and oral cavity [22], as well as in certain experimental models of carcinogenesis. [23] Several studies have reported an association between low systemic levels of folate and/or vitamin $B_{12}$ and an increased risk of cancer and precancer in epithelial tissues. $[24,25]$ Mucosal atrophy is a common feature of various conditions considered to increase the liability to oral cancer and precancer [26]. In experimental animals, iron deficiency lead to changes in the cell kinetics [27] and mild iron deficiency levels, which are associated with increased oxidative stress, increase the risk of oral cavity cancer [28].
Epidemiological and clinical evidence suggest that foliate deficiency in certain epithelial tissue, regardless of systemic folate status, may be a factor that predispose to the development of neoplasms arising from these tissues [29]. Folate supplementation thought to have resulted in correction of cellular abnormalities associated with diminished folate status. [20] And profound vitamin $B_{12}$ deficiency can cause moderateto-severe oral mucosal dysplasia that resolves after correction of the vitamin $B_{12}$ deficiency [30].

Several studies have reported alterations in circulating levels of vitamin $\mathrm{B}_{12}$ and folate in humans due to the habit of tobacco smoking or chewing [31,32], but there is paucity of information about the role of folate and vitamin $B_{12}$ in OED, thus, the aim of this study was: to establish the circulating levels of the vitamin $B_{12}$, serum folate, red blood cells folate in patients with OED and to compare these levels with the values obtained in normal control subjects with and without tobacco smoking.

\section{Materials and methods}

\section{Study population}

The study group comprised a total of 120 patients with histologically confirmed OED (64 males, 56 females, median age 54 years, range 29-80) attending the Oral Surgery Oral Medicine Department of the College of Dentistry, Ajman University, United Arab Emirates between 2002 and June 2012 were selected for the study after obtaining their

Correspondence to: Mohamed A Jaber, Department of Oral Surgery, Hamdan Bin Mohamed College of Dental Medicine, Mohammed Bin Rashid University of Medicine and Health Sciences, Dubai P. O. Box 505097, United Arab Emirates. Tel: (+971) 044248630; E-mail : mjaber4@hotmail.com; mohamed.jaber@mbru.ac.ae

Key words: Folate, Oral epithelial dysplasia, Vitamin B12, Tobacco

Received: October 02, 2017; Accepted: October 17, 2017; Published: October 21, 2017 
informed consent. Control subjects were selected from those attending the college dental clinics with oral diseases not caused by smoking or drinking or related to known hematinic deficiency. Control participants were from same geographic area as the patients. Patients and control subjects were matched for gender, and date of birth (within 5 years). A total of 120 patients with OED and 120 control subjects were included in the study. Case and control subjects were interviewed in person and relevant data was collected in a standard, structured questionnaire. Information on prior use of tobacco and alcohol, type, site, duration of the dysplastic lesions, Dysplastic lesions have been classified microscopically according to degree of cytologic atypia and changes in architectural patterns, by a single pathologist into mild, moderate and severe dysplasia [1]. A current smoker was defined as someone who had smoked within the year preceding diagnosis, and previous smoker as someone who had smoked but had stopped more than one year prior to diagnosis. Questions regarding the major parameters of tobacco use included: type of tobacco used (filter cigarettes, cigars, pipe, rollup and chewing tobacco/taking snuff, chew betel quid); duration of smoking in years; average number of cigarette smoked per day. Data on alcohol consumption included: type of alcoholic beverage used, amount of alcohol consumed per day (glass/daily) and total duration of drinking in years. Because most of the patients with OED (74.2\%) were smokers, and because cigarette smoking can determine alterations in vitamin $B_{12}$, and folate status and may be a confounding factor, the results from patients with OED was compared with the results from an age-matched and gender-matched control group of 59 smokers and with the results from another age-matched and gender-matched control group of 61 nonsmokers. All participants in the smoker group were current smokers, and all participants in the non-smoker group did not ever smoke. Because heavy alcohol drinking can alter folate absorption and metabolism and also considered as a risk factor for head and neck carcinoma and OED, this may have a confounding effect in the study, thus any known heavy drinkers were excluded from the study. No participants who were included in the study had received folate or vitamin $B_{12}$ supplements in the last 6 months before the study. In addition, nutritional status may be the primary determinant of folate and vitamin $B_{12}$ levels so any participant with clinically evident nutritional deficiencies was excluded from the study. All subjects gave written informed consent to participate in the study. The institutional review board of the College of Dentistry, Ajman University, approved the study protocol.

A venous blood sample was drawn from each patient and control subject and divided for determination of serum folate, red blood cell folate, vitamin $\mathrm{B}_{12}$. Blood samples were stabilized and frozen at $-70^{\circ} \mathrm{C}$ until assayed. The complete blood count (CBC) included determination of haemoglobin, red blood cell, red blood cell indices, and white blood cells with differential using standard methods. All blood samples from patients and controls were drawn in the morning to provide consistency in interpretation of results. Serum folate, whole blood folate and RBC folates were measured in duplicate using standard technique $[33,34]$. None of the patients or controls was taking any medications at the time of testing.

\section{Data analysis}

Statistical procedures were carried out using the SPSS programme [version 21, SPSS Inc., Chicago, IL, USA for Windows]. Analysis of the differences between serum folate, red blood cell folate, vitamin $B_{12}$, iron, total iron binding capacity and ferritin among cases and controls was carried out using Student's t-test. Significance was accepted when the $p$-value was less than 0.05 .

\section{Results}

\section{Demographic details}

Age and gender distribution of the study subjects is detailed in (Table 1). Most cases were male (53.3\%), and the median age at diagnosis of the patients was 54 years (range 29 to 80 ). The majority of OED were graded as mild $(46.7 \%)$ or moderate $(40.0 \%)$ epithelial dysplasia.

Serum folate, red blood cell folate and vitamin $B_{12}$ among cases and control subjects

Mean serum levels of vitamin $B_{12}$, folate, and red blood cells folate in normal non-smokers and smokers control subjects compared with OED are detailed in (Table 2). A significant decrease in the serum levels of folate, red blood cell folate were found in OED compared to normal tobacco smokers $(p<0.05)$. No significant differences in vitamin $\mathrm{B}_{12}$ was found between OED cases and normal control subjects.

\section{Tobacco and alcohol habits of subjects}

Tobacco and alcohol usage are detailed in (Table 3). Significantly more of OED patients were current tobacco smokers of more than 20 cigarettes per day for more than 20 years compared with normal healthy control.

\section{Discussion}

It is generally agreed that tobacco consumption is a major aetiological factor for OED and many studies have shown an overrepresentation of tobacco smokers amongst patients with OED [8-11]. In this study tobacco smoking was recorded in at least $74.2 \%$ of patients with OED compared with $49.0 \%$ in healthy controls thus confirm the significance of tobacco smoking and alcohol consumption as risk factors in the aetiology of OED.

One of the harmful effects of tobacco consumption is the alteration in the plasma/serum levels of micronutrients $[13,25,32,35]$. In this study a decrease in the plasma folate levels was observed in the patients consuming tobacco as compared to the nonsmokers, thus confirming the observation of Almadori et al. from Italy [36] who found that serum

Table 1. Demographic characteristics of patients with oral epithelial dysplasia and control subjects

\begin{tabular}{|l|c|c|c|c|}
\hline Variables & \multicolumn{2}{|c|}{ Cases } & \multicolumn{2}{c|}{ Control } \\
\hline Age (years) & No & & & No \\
$<30$ & 1 & 0.8 & 3 & 2.5 \\
$30-50$ & 43 & 35.8 & 40 & 33.3 \\
$51-70$ & 60 & 50.0 & 57 & 47.5 \\
$>70$ & 16 & 13.3 & 20 & 16.7 \\
Total & 120 & 100.0 & 120 & 100.0 \\
\hline Gender & & & & \\
Male & 64 & 53.3 & 64 & 53.3 \\
Female & 56 & 46.7 & 56 & 46.7 \\
Total & 120 & 100.0 & 120 & 100.0 \\
\hline Marital status & & & & \\
Single & 10 & 8.3 & 15 & 12.5 \\
Married & 81 & 67.5 & 72 & 60.0 \\
Widow & 17 & 14.1 & 19 & 15.8 \\
Divorce & 12 & 10.0 & 14 & 100.0 \\
Total & 120 & 100.0 & 120 & \\
\hline Oral epithelial & & & & \\
dysplasia & & & & \\
Mild & 56 & 46.7 & & \\
Moderate & 48 & 40.0 & & \\
Severe & 16 & 13.3 & & \\
Total & 120 & 100.0 & & \\
\hline
\end{tabular}


Table 2. Serum and Red Blood cell folate and serum vitamin $B_{12}$ in patients with oral epithelial dysplasia and control subjects

\begin{tabular}{|c|c|c|c|c|c|c|c|}
\hline \multirow{2}{*}{ Groups } & \multirow{2}{*}{ No } & \multicolumn{2}{|c|}{ Serum Folate $\boldsymbol{\mu g} / \mathbf{l}$} & \multicolumn{2}{|c|}{ RBC folate $\mathrm{g} / \mathbf{l}$} & \multicolumn{2}{|c|}{ B12 ng/l } \\
\hline & & Mean & \pm SD & Mean & \pm SD & Mean & \pm SD \\
\hline (A) Oral dysplasia & 120 & 3.1 & 2.9 & 228.8 & 38.7 & 277.6 & 20.3 \\
\hline Controls & & & & & & & \\
\hline (B) Smokers & 59 & 13.7 & 2.6 & 587.0 & 18.7 & 272.3 & 16.3 \\
\hline (C) Non-smokers & 61 & 10.1 & 2.8 & 504.6 & 19.2 & 326.9 & 19.2 \\
\hline (D) Drinkers & 55 & 3.4 & 3.1 & 350.9 & 16.3 & 308.7 & 17.6 \\
\hline (E) Non-drinkers & 65 & 3.7 & 3.1 & 392.6 & 14.2 & 317.0 & 24.1 \\
\hline
\end{tabular}

S.D. $=$ Standard deviation

Significance (t-test):

Serum Folate

A vs B $P<0.05$

A vs $C P=0.07$

A vs $\mathrm{D} P=0.9$

\section{RBC folate}

A vs $\mathrm{B} P<0.05$

A vs $C P=0.09$

A vs $\mathrm{D} P=0.7$

Vitamin B12

A vs E $P=0.9$

A vs E $P=0.6$

A vs B $P=0.9$

A vs $\mathrm{C} P=0.5$

A vs $\mathrm{D} P=0.8$

A vs E $P=0.7$

Table 3. Frequency of tobacco and alcohol usage in 120 patients with oral epithelial dysplasia and healthy control subjects

\begin{tabular}{|c|c|c|c|}
\hline Habits & $\begin{array}{c}\text { Cases } \\
\text { No }(\%)\end{array}$ & $\begin{array}{l}\text { Controls } \\
\text { No }(\%)\end{array}$ & $\begin{array}{c}\text { Chi-square test } \\
P \text { value }\end{array}$ \\
\hline $\begin{array}{l}\text { Tobacco smoking } \\
\text { Yes } \\
\text { No } \\
\text { Total }\end{array}$ & $\begin{array}{c}89(74.2) \\
31(25.8) \\
120(100.0\end{array}$ & $\begin{array}{c}59(49.1) \\
61(50.9) \\
120(100.0)\end{array}$ & $\begin{array}{c}15.86 \\
<0.001\end{array}$ \\
\hline $\begin{array}{l}\text { Years smoking } \\
1-19 \\
20-39 \\
>39 \text { years } \\
\text { Total }\end{array}$ & $\begin{array}{l}15(16.8) \\
41(46.0) \\
33(37.2) \\
89(100.0)\end{array}$ & $\begin{array}{c}34(57.6) \\
18(30.5) \\
7(11.8) \\
59(100.0)\end{array}$ & $\begin{array}{c}60.96 \\
<0.001\end{array}$ \\
\hline \begin{tabular}{|l|} 
Type of tobacco \\
habit \\
Filter \\
Non filter \\
Total \\
\end{tabular} & $\begin{array}{c}61(68.5) \\
28(31.5) \\
89(100.0)\end{array}$ & $\begin{array}{c}41(69.4) \\
18(30.5) \\
59(100.0)\end{array}$ & $\begin{array}{c}0.15 \\
>0.001\end{array}$ \\
\hline $\begin{array}{l}\text { Cigarette (per day) } \\
1-9 \\
10-19 \\
20-29 \\
>29 \\
\text { Total }\end{array}$ & $\begin{array}{c}8(9.0) \\
19(21.3) \\
30(33.7) \\
32(36.0) \\
89(100.0)\end{array}$ & $\begin{array}{c}22(37.2) \\
15(25.4) \\
13(22.0) \\
9(15.2) \\
59(100.0)\end{array}$ & $\begin{array}{l}117.77 \\
<0.001\end{array}$ \\
\hline $\begin{array}{l}\text { Alcohol } \\
\text { consumption } \\
\text { Yes } \\
\text { No } \\
\text { Total }\end{array}$ & $\begin{array}{c}18(15.0) \\
102(85.0) \\
120(100.0)\end{array}$ & $\begin{array}{c}55(45.8) \\
65(54.2) \\
120(100.0)\end{array}$ & $\begin{array}{c}26.95 \\
<0.001\end{array}$ \\
\hline
\end{tabular}

folate levels were significantly lower in patients with head and neck carcinoma and in patients with laryngeal leukoplakia compared with serum folate levels in both the smoker and nonsmoker control group. Likewise, Ramaswamy et al. (25] have reported low levels of vitamin $\mathrm{B}_{12}$ and folate in a group of Indian patients with oral leukoplakia, furthermore, several other investigators have suggested that deficiency of folate enhances development of preneoplastic and neoplastic lesions, which are suppressed by folate supplementation [37]. Low folate level probably does not have an independent role as an initiating factor. Instead, presumably, acts synergistically with other genetic and environmental factors, such as tobacco carcinogens, making cells more susceptible to mutagens and increasing the rate of tumor progression. Some of the carcinogenic substances present in tobacco smoke 'primarily organic nitrites, cyanates, and isocyanates', have been shown to interact with folate and vitamin $\mathrm{B}_{12}$ coenzymes, transforming them into biologically inactive compounds [32,38]. These chemical interactions may have physiological significance is supported by reports of lower circulating folate $[39,40]$ and $B_{12}$ [41] levels in smokers and the buccal mucosal cells of tobacco smokers were shown to have a decreased concentration of folate [35].

The rationale for folate's possible protection against cancer is based on its roles in DNA synthesis and repairing damaged DNA [42,43]. Folate is involved in DNA methylation, through which it may influence gene stability and expression [43]. The benefits of folate [20,42] cobalamin [20] in reducing the risk of cancer or precancer in epithelial tissues have been reported in the literature.

Eto and Krumdieck [37] in a review of the role of vitamin $B_{12}$ and folate deficiencies in carcinogenesis, observed that neither deficiency is carcinogenic by itself but that each may increase susceptibility to the action of other carcinogens. A deficiency of folate has also been reported to enhance the expression of endogenous and exogenous oncogenes [23]. It is generally acknowledged that RBC folate levels provide a more accurate indication of long term nutritional status than plasma or serum folate level, which is influenced by recent ingestion of food. The findings of this study provide evidence that inadequate reserve of folate, as reflected in RBC folate contents may enhance the effect of tobacco smoking on OED risk. Furthermore, low level of folate was found to be related to an increased risk of epithelial dysplasia or carcinoma-in-situ $[44,45]$. These nutrients are likely to take the active role in the risk reduction effect.

Vitamin $B_{12}$ deficiency reportedly has been associated with chromosomal damage to buccal mucosal cells in smokers [46] and vitamin $B_{12}$ and folate supplementation in the treatment of precancerous lesions like cervical dysplasia and bronchial metaplasia have been reported [42,47]. Nevertheless, in the current study focused on OED, differences in vitamin $B_{12}$ serum levels between OED patients and healthy control subjects lacked significance.

Hematological abnormalities in oral cancer and precancerous lesions were reported by Khanna and Karjodkar [48], and the abnormalities may be associated with the pathogenesis and progressions of oral cancer and potentially malignant lesions. It has been suggested that mucosal atrophy, increased mitotic activity, and diminished repair capacity are among the major common underlying predisposing factors in oral cancer and potentially malignant lesions [49].

It is recognized however, that in certain cases other associated deficiencies of essential nutrients and vitamins may arise and complicate the situation [50]. Nutritional factors are of great importance in maintaining the integrity of the oral mucosa $[27,51]$ and thorough hematinic investigation is recommended in the management of potentially malignant oral lesions, particularly in patients in whom these deficiencies are prevalent [52].

These findings support the notion that OED may develop in persons who expose to tobacco smoking and have low folate level, however, clinical trials to investigate the effectiveness of supplementation of this micronutrient in reducing the incidence of oral OED and its subsequent malignant transformation may be warranted.

\section{Acknowledgment}

I would like to acknowledge the help and contribution of the other doctors and assisting staff.

\section{Conflict of interests}

The author confirms that there are no any conflicts of interest to be declared. 


\section{References}

1. Hazarey V, Daftary D, Kale A, Warnakulasuriya S (2007) Proceedings of the panel discussion on 'standardized reporting of oral epithelial dysplasia'. J Oral Maxillofac Pathol 11: 86-88.

2. Jaber MA, Porter SR, Speight P, Eveson JW, Scully C (2003) Oral epithelial dysplasia: Clinical characteristics of western European residents. Oral Oncol 39: 589-596. [Crossref]

3. Gregg TA, Cowan CG, Kee F (1992) Trends in the relative frequency of histologically diagnosed epithelial dysplasia and intra-oral carcinoma in Northern Ireland, 19751989. Br Dent J 173: 234-236. [Crossref]

4. Crissman J, Zarbo R (1993) Dysplasia, in-situ carcinoma, and progression to invasive squamous cell carcinoma of the upper aerodigestive tract. Am J Pathol 13: 5-16. [Crossref]

5. Silverman S Jr, Gorsky M, Lozada F (1984) Oral leukoplakia and malignant transformation. A follow-up study of 257 patients. Cancer 53: 563-568. [Crossref]

6. Lumerman H1, Freedman P, Kerpel S (1995) Oral epithelial dysplasia and the development of invasive squamous cell carcinoma. Oral Surg Oral Med Oral Pathol Oral Radiol Endod 79: 321-329. [Crossref]

7. Maserejian NN, Joshipura KJ, Rosner BA, Giovannucci E, Zavras AI (2006) Prospective study of alcohol consumption and risk of oral premalignant lesions in Men. Cancer Epidemiol Biomarkers Prev 15: 774-781. [Crossref]

8. Macigo FG, Mwaniki DL, Guthua SW (1995) The association between oral leukoplakia and use of tobacco, alcohol and khat based on relative risks assessment in Kenya. Eu J Oral Sci 103: 268-273. [Crossref]

9. Jaber MA, Porter SR, Scully C, Gilthorpe MS, Bedi R (1998) The role of alcohol in non-smokers and tobacco in non-drinkers in the aetiology of oral epithelial dysplasia. Int J Cancer 77: 333-336. [Crossref]

10. Jaber MA, Porter SR, Gilthorpe MS, Bedi R, Scully C (1999) Risk factors for ora epithelial dysplasia--the role of smoking and alcohol. Oral Oncol 35: 151-156. [Crossref]

11. Kulasegaram R, Downer MC, Jullien JA, Zakrzewska JM, Speight PM (1995) Casecontrol study of oral dysplasia and risk habits among patients of a dental hospital. Eur J Cancer B Oral Oncol 31B: 227-231. [Crossref]

12. Morse DE, Katz RV, Pendrys DG, Holford TR, Krutchkoff DJ, et al. (1996) Smoking and drinking in relation to oral epithelial dysplasia. Cancer Epidemiol Biomarkers Prev 5: 769-777. [Crossref]

13. Piyathilake CJ, Macaluso M, Hine RJ, Richards EW, Krumdieck CL (1994) Local and systemic effects of cigarette smoking on folate and vitamin B-12. Am J Clin Nutr 60: 559-566. [Crossref]

14. Zain RB (2001) Cultural and dietary risk factors of oral cancer and precancer--a brief overview. Oral Oncol 37: 205-210. [Crossref]

15. Petti S (2009) Lifestyle risk factors for oral cancer. Oral Oncol 45: 340-350. [Crossref]

16. Morse DE, Pendrys DG, Katz RV, Holford TR, Krutchkoff DJ, et al. (2000) Food group intake and the risk of oral epithelial dysplasia in a United States population. Cancer Causes Control 11: 713-720. [Crossref]

17. Stich HF, Mathew B, Sankaranarayanan R, Nair MK (1991) Remission of precancerous lesions in the oral cavity of tobacco chewers and maintenance of the protective effect of beta- carotene or vitamin A. Am J Clin Nutr 53: 2983-3048.

18. Benner SE, Winn RJ, Lippman SM, Poland J, Hansen KS, et al. (1993) Regression of oral leukoplakia with alpha-tocopherol: a community clinical oncology program chemoprevention study. J Natl Cancer Inst 85: 44-47. [Crossref]

19. Jaskewicz K, Marasas WF, Lazarus C, Beyers AD, van Helden PD (1988) Association of oesophageal cytological abnormalities with vitamin and lipotrope deficiencies in population at risk for oesophageal cancer. Anticancer Res 8: 71-76.

20. Heimburger DC, Alexander CB, Birch R, Butterworth CE Jr, Bailey WC, et al. (1998) Improvement in bronchial squamous metaplasia in smokers treated with folate and vitamin B12. J Am Med Assoc 289: 1525-1530. [Crossref]

21. Butterworth CE (1991) Folate deficiency and cancer. In: A. Bendich, C. E. Butterworth Editors: Micronutrients in health and disease. New York: Marcel Decker 165-183.

22. Almadori G, Bussu F, Galli J, Cadoni G, Zappacosta B, et al. (2002) Serum folate and homocysteine levels in head and neck squamous cell carcinoma. Cancer 94: 10061011. [Crossref]

23. Hsieh LL, Wainfan E, Hoshina S, Dizik M, Weinstein IB (1989) Altered expression of retrovirus-like sequences and cellular oncogenes in mice fed methyl-deficient diets. Cancer Res 49: 3795-3799. [Crossref]
24. Sankaranarayanan R, Duffy SW, Day NE, Nair MK, Padmakumary G (1989) A casecontrol investigation of cancer of the oral tongue and the floor of the mouth in southern India. Int J Cancer 44: 617-621. [Crossref]

25. Ramaswamy G, Rao VR, Kumaraswamy SV, Anantha N (1996) Serum vitamins' status in oral leucoplakias--a preliminary study. Eur J Cancer B Oral Oncol 32B: 120-122. [Crossref]

26. MacDonald DG (1975) Premalignant lesions of oral mucosa. In: A. E. Dolby. edit. Oral mucosa in health and disease. Oxford: Blackwell Scientific publications 335-369.

27. Rennie JS, MacDonald DG, Dagg JH (1984) Iron and the oral epithelium: a review. $J$ $R$ Soc Med 77: 602-607. [Crossref]

28. Richie JP Jr, Kleinman W, Marina P, Abraham P, Wynder EL, et al. (2008) Blood iron, glutathione, and micronutrient levels and the risk of oral cancer. Nutr Cancer 60 : 474-482. [Crossref]

29. Heimburger DC (1992) Localized deficiencies of folic acid in aerodigestive tissues. Ann N Y Acad Sci 669: 87-95. [Crossref]

30. Theaker JM, Porter SR, Fleming KA (1989) Oral epithelial dysplasia in vitamin B12 deficiency. Oral Surg Oral Med Oral Pathol 67: 81-83. [Crossref]

31. Khalid MA, Watkins CL, Krumdieck CL (1986) Inactivation of B12 and folate coenzymes by butylnitrite as observed by NMR: implications on one-carbon transfe mechanism. Biochem Biophys Res Commun 135: 201-207. [Crossref]

32. Hecht SS (1999) Tobacco smoke carcinogens and lung cancer. J Natl Cancer Inst 91 1194-1210. [Crossref]

33. Longo DL, Herbert V (1976) Radioassay for serum and red cell folate. J Lab Clin Med 87: 138-151. [Crossref]

34. Waxman S, Schreiber C, Herbert V (1971) Radioisotopic assay for measurement of serum folate levels. Blood 38: 219-228. [Crossref]

35. Piyathilake CJ, Hine RJ, Dasanayake AP, Richards EW, Freeberg LE, et al. (1992) Effect of smoking on folate levels in buccal mucosal cells. Int J Cancer 52: 566-569. [Crossref]

36. Almadori G, Bussu F, Galli J, et al. (2005) Serum levels of Folate, Homocysteine, and Vitamin B12 in Head and Neck squamous cell carcinoma and in laryngeal leukoplakia. Cancer 103: 284-292. [Crossref]

37. Eto I, Krumdieck CL (1986) Role of vitamin B12 and folate deficiencies in carcinogenesis. Adv Exp Med Biol 206: 313-330. [Crossref]

38. Khaled MA, Krumdieck CL (1985) Association of folate molecules as determined by proton NMR: implications on enzyme binding. Biochem Biophys Res Commun 130: 1273-1280. [Crossref]

39. Witter FR, Blake DA, Baumgardner R, Mellits ED, Niebyl JR (1982) Folate, carotene, and smoking. Am J Obstet Gynecol 144: 857. [Crossref]

40. Nakazawa Y, Chiba K, Imatoh N, Kotorii T, Sakamoto T, et al. (1983) Serum folic acid levels and antipyrine clearance rates in smokers and non-smokers. Drug Alcohol Dependence 11: 210-217. [Crossref]

41. Dastur DK, Quadros EV, Wadia NH, Desai MM, Bharucha EP (1972) Effect of vegetarianism and smoking on vitamin B12, thiocyanate, and folate levels in the blood of normal subjects. Br Med J 3: 260-263. [Crossref]

42. Butterworth CE Jr, Hatch KD, Macaluso M, Cole P, Sauberlich HE, et al. (1992) Folate deficiency and cervical dysplasia. JAMA 267: 528-533. [Crossref]

43. Mason JB, Levesque T (1996) Folate: effects on carcinogenesis and the potential for cancer chemoprevention. Oncology (Williston Park) 10: 1727-1736, 1742-3. [Crossref]

44. Buckley D, McPherson RS, North CQ, Becker TM (1992) Dietary micronutrients and cervical dysplasia in South-Western Indian women. Nutr Cancer 17: 179-185.

45. Correa P (1992) Vitamins and cancer prevention. Cancer Epidemiol Biomarkers Prev 1: 241-243. [Crossref]

46. Piyathilake CJ, Macaluso M, Hine RJ, Vinter DW, Richards EW, et al. (1995) Cigarette smoking, intracellular vitamin deficiency, and occurrence of micronuclei in epithelia cells of the buccal mucosa. Cancer Epidemiol Biomarkers Prev 4: 751-758. [Crossref]

47. Saito M, Kato H, Tsuchida T, Konaka C (1994) Smokers metaplasia by folate and vitamin B12 in heavy chemoprevention effects on bronchial squamous. Chest 106:496499. [Crossref]

48. Khanna SS, Karjodkar FR (2006) Circulating Immune Complexes and trace elements (Copper, Iron and Selenium) as markers in oral precancer and cancer: a randomised, controlled clinical trial. Head \& Face Med 2: 1-10. [Crossref] 
49. Ramanathan K (1981) Oral submucous fibrosis--an alternative hypothesis as to its causes. Med J Malaysia 36: 243-245. [Crossref]

50. Morse ED, Pendrys GD, Katz VR, et al. (2000) Food group intake and the risk of oral epithelial dysplasia in a United States population. Cancer Causes Control 1: 713-720. [Crossref]
51. Mitchell K, Ferguson MM, Lucie NP, MacDonald DG (1986) Epithelial dysplasia in the oral mucosa associated with pernicious anaemia. Br Dent $J$ 161: 259-260. [Crossref]

52. Warnakulasuryia KA, Prabhu SR (1992) Anaemia in the Tropics. In: Prabhu S.R, Wilson D.F, Daftary D.K, Johnson N.W, editors. Oral diseases in the Tropics. Oxford Medical Publications: 325-336.

Copyright: (C2017 Jaber MA. This is an open-access article distributed under the terms of the Creative Commons Attribution License, which permits unrestricted use, distribution, and reproduction in any medium, provided the original author and source are credited. 